Restoring the Balance 



\section{Restoring the Balance}

WOMEN PHYSICIANS AND THE

PROFESSION OF MEDICINE, 1850-1995

Ellen S. More

HARVARD UNIVERSITY PRESS

Cambridge, Massachusetts

London, England 
Copyright () 1999 by the President and Fellows of Harvard College All rights reserved

Printed in the United States of America

Second printing, 2000

Library of Congress Cataloging-in-Publication Data

More, Ellen Singer, 1946-

Restoring the balance : women physicians and the profession of medicine, 1850-1995 / Ellen S. More.

p. $\mathrm{cm}$.

Includes bibliographical references and index.

ISBN 0-674-76661-X (alk. paper)

ISBN 0-674-00567-8 (pbk.)

1. Women physicians-United States-History 19th century.

2. Women physicians-United States-History 20th century.

3. Women in medicine-United States-History 19th century.

4. Women in medicine-United States-History 20th century.

I. Title. [DNLM: 1. Physicians, Women-United States.

2. Feminism-history-United States.

3. History of Medicine, 20th Cent.-United States.

WZ 80.5.W5 M835r 1999]

R692.M645 1999

$610.69^{\prime} 52^{\prime} 0820973-\mathrm{dc} 21$ 
This book is dedicated with love to my husband, Micha Hofri, and to my daughter, Betsy More. Without their love and support - and humor-I surely would have lost my own sense of balance. I dedicate it, too, to the memory of my parents, Ben and Dorothy Cooperman Singer. 
